\title{
Beta-cell hypersensitivity for glucose precedes loss of glucose-induced insulin secretion in $90 \%$ pancreatectomized rats
}

\author{
J. L. Leahy, L. M. Bumbalo, C. Chen \\ Division of Endocrinology, Metabolism, and Molecular Medicine, New England Medical Center, and Tuft's University School of Medicine, \\ Boston, Massachusetts, USA
}

\begin{abstract}
Summary. Glucose-induced insulin secretion is impaired in the presence of chronic hyperglycaemia. Insulin secretion was studied in a diabetic rat model prior to the beta cells becoming non-responsive to glucose in order to map out the sequence of changes that accompany chronic hyperglycaemia. In vitro pancreas perfusions were carried out 1 and 2 weeks after a $90 \%$ pancreatectomy; controls underwent a sham pancreatectomy. One week post $90 \%$ pancreatectomy: (i) non-fasting plasma glucose values were $2-3 \mathrm{mmol} / \mathrm{l}$ above normal, (ii) the in vitro insulin response to $16.7 \mathrm{mmol} / 1 \mathrm{glu}-$ cose was $20 \pm 4 \%$ of shams, a response that was appropriate for the surgical reduction in beta-cell mass, (iii) the beta-cell sensitivity for glucose was increased as reflected by leftshifted dose-response curves for glucose-induced insulin se-
\end{abstract}

cretion (half maximal insulin output $5.7 \mathrm{mmol} / \mathrm{l}$ glucose vs $16.5 \mathrm{mmol} / \mathrm{l}$ glucose in shams) and glucose potentiation of arginine-induced insulin secretion (half maximal insulin output $3.5 \mathrm{mmol} / 1$ glucose vs $14.8 \mathrm{mmol} / 1$ glucose in shams). This heightened beta-cell sensitivity for glucose was not a result of the hyperglycaemia, because similarly reduced half-maximal insulin responses were found after a $60 \%$ pancreatectomy, a surgical procedure in which plasma glucose values remained normal. In summary, a rise in beta-cell sensitivity for glucose precedes the loss of glucose-induced insulin secretion in diabetic rats.

Key words: Islets of Langerhans, insulin secretion, perfused pancreas, glucose, arginine, partial pancreatectomy.
The characteristic insulin secretion defect in Type 2 (noninsulin-dependent) diabetes mellitus is an impaired influence of glucose over insulin secretion [1,2]. A substantial body of information, much of it from animal models, has suggested that chronic exposure of beta cells to an elevated plasma glucose concentration causes the glucose unresponsiveness $[1,3]$. However, the same secretory defect is found in animal models where glucose values are raised less than $1 \mathrm{mmol} / \mathrm{l}$ [4-6]. Still unresolved is how such a small increase in plasma glucose causes beta-cell dysfunction.

We recently observed another insulin secretion defect in rats made diabetic by the administration of streptozotocin during the neonatal period. A dose-response curve for glucose-induced insulin secretion was constructed after first causing recovery of glucose responsiveness by perfusing the pancreas in vitro for 40 min with buffer containing no glucose [7]. The curve in the diabetic rats was shifted to the left so that half-maximal insulin secretion occurred at $8.3 \mathrm{mmol} / \mathrm{l}$ glucose vs $13.2 \mathrm{mmol} / \mathrm{l}$ in control rats [8]. In addition, Sako and Grill [9] reported that diazoxide (an inhibitor of insulin secretion) prevented the loss of glucose-induced insulin secretion in rats made hyperglycaemic with glucose infusions. They concluded that excessive stimulation of insulin secretion was one mechanism for the beta-cell dysfunction in these rats.

Based on these results, we hypothesized that mild hyperglycaemia causes beta-cell dysfunction through a cascade of events. First, glucose sensitivity increases as reflected by a left-shift in glucose-induced insulin secretion. This adaptive enhancement of insulin secretion at submaximal glucose levels causes the beta cells to function as if the hyperglycaemia were worse than it actually is. It is this overactivity which leads to the next step in the process, the intracellular events which cause glucose-induced insulin secretion to become impaired.

This study uses a partial pancreatectomy rat model to test the first part of this hypothesis, that a hypersensitivity for glucose predates the loss of glucose-induced insulin secretion in diabetic rats. Rats were studied after $90 \%$ pancreatectomy. These rats are hyperglycaemic, and the beta cells in the remaining $10 \%$ of the pancreas develop the typical features of hyperglycaemia-induced dysfunction, lack of glucose-induced insulin secretion while that to non-glucose secretagogues such as arginine is intact [10, 11]. Rats were also studied after a $60 \%$ pancreatectomy. 
These rats are not hyperglycaemic, and glucose-induced insulin secretion remains at a level which is appropriate for the reduction in beta-cell mass, i.e. $40 \%$ of normal $[5$, 12]. The aims of the study were to determine: 1 ) is the dose-response curve for glucose-induced insulin secretion left-shifted after a $90 \%$ pancreatectomy? 2) does the hypersensitivity for glucose predate the disappearance of glucose-induced insulin secretion? 3) does hyperglycaemia cause the heightened beta-cell sensitivity for glucose?

\section{Materials and methods}

Partial pancreatectomy rat model (Px). Partial pancreatectomies were performed on 5-week-old male Sprague-Dawley rats (Taconic, Germantown, NY, USA) using the method of Bonner-Weir et al. [10]. During pentobarbital sodium anaesthesia (100 mg/kg i.p.), a midline abdominal incision was made and the pancreas was mobilized by gently breaking mesenteric connections with the stomach, bowel, and retroperitoneum. Cotton applicators were used to abrade pancreatic tissue away from the major blood vessels. A $90 \%$ Px entailed removing the pancreas in toto except for the portion bordered by the bile duct and the duodenum [10]. A $60 \%$ Px consisted of removing the splenic lobe of the pancreas up to, but not including, the small flap attached to the pylorus [5]. Control rats (shams) underwent laparotomy and mobilization of the pancreas. Post-operatively, rats were given rat chow and tap water ab libitum.

In vitro perfused pancreas. This technique has been described in detail elsewhere [13]. On the day of perfusion, blood (non-fasting) was obtained at 09.00 hours for plasma glucose measurements. The per-

Table 1. Post-operative body weight and plasma glucose values

\begin{tabular}{|c|c|c|c|c|}
\hline \multirow[t]{2}{*}{$\begin{array}{l}\% \text { Pancreat- } \\
\text { ectomy }(\mathrm{Px})\end{array}$} & \multicolumn{2}{|c|}{ Body weight (g) } & \multicolumn{2}{|c|}{$\begin{array}{l}\text { Plasma glucose } \\
(\mathrm{mmol} / \mathrm{l})\end{array}$} \\
\hline & 1 week & 2 weeks & 1 week & 2 week \\
\hline Sham & $158 \pm 3$ & $207 \pm 5$ & $8.1 \pm 0.2$ & $8.4 \pm 0.2$ \\
\hline $60 \% \mathrm{Px}$ & & $213 \pm 4$ & & $8.9 \pm 0.2$ \\
\hline $90 \% \mathrm{Px}$ & $140 \pm 3^{a}$ & $200 \pm 5$ & $10.6 \pm 0.7^{\mathrm{b}}$ & $11.8 \pm 0.8^{b}$ \\
\hline
\end{tabular}

Values are expressed as mean \pm SEM. Number of animals in each group: sham operated rats at 1 week (16) and 2 weeks (18), 60\% Px 2 weeks (15), 90\% Px 1 week (18) and 2 weeks (18). The plasma glucose values are non-fasting

${ }^{\mathrm{a}} p<0.005,{ }^{\mathrm{b}} p<0.001$; Statistical significance was determined between Px rats and the time-matched sham group fusate was a Krebs-Ringer bicarbonate buffer $\mathrm{pH} 7.4$ plus $4 \%$ dex$\operatorname{tran} \mathrm{T}_{70}$ (Sigma, St. Louis, Mo., USA), $2 \mathrm{mmol} / 1 \mathrm{Ca}^{2} \div, 1.2 \mathrm{mmol} / 1$ $\mathrm{Mg}^{2+}$, and $0.2 \%$ bovine serum albumin fraction $\mathrm{V}$ (Sigma), at a flow rate of $3 \mathrm{ml} / \mathrm{min}$. Following cannulation of the aorta and portal vein, the body cavity was covered with gauze soaked in saline and maintained at $36-39^{\circ} \mathrm{C}$ by a heat lamp. Each protocol began with an equilibration period of at least $20 \mathrm{~min}$. Thereafter, 1 -min samples were collected in tubes containing $8 \mathrm{mg}$ EDTA and kept on ice pending storage at $-20^{\circ} \mathrm{C}$.

\section{Protocols}

1. $90 \% \mathrm{Px}$ and sham rats underwent pancreas perfusion 1 or 2 weeks post-surgery. The protocol was 20 -min equilibration at $5.5 \mathrm{mmol} / 1$ glucose followed by $15 \mathrm{~min} 16.7 \mathrm{mmol} / 1$ glucose and $15 \mathrm{~min}$ $10 \mathrm{mmol} / \mathrm{l}$ arginine $+16.7 \mathrm{mmol} / 1$ glucose.

2. $90 \%$ Px and sham rats underwent pancreas perfusion 1 or 2 weeks post-surgery. The protocol was 40 -min equilibration at $0 \mathrm{mmol} / \mathrm{glu}$ cose followed by $15 \mathrm{~min} 5.5,11.1,16.7$, or $27.7 \mathrm{mmol} / \mathrm{l}$ glucose and $15 \mathrm{~min} 10 \mathrm{mmol} / \mathrm{l}$ arginine + the same glucose concentration.

3. $60 \%$ Px rats underwent pancreas perfusion 2 weeks post-surgery. The protocol was $40-\mathrm{min}$ equilibration at $0 \mathrm{mmol} / 1$ glucose followed by $15 \mathrm{~min} 5.5,11.1,16.7$, or $27.7 \mathrm{mmol} / \mathrm{l}$ glucose and $15 \mathrm{~min}$ $10 \mathrm{mmol} / \mathrm{l}$ arginine + the same glucose concentration.

Analytical methods. Plasma glucose was measured with a Beckman Glucose Analyzer II (Beckman, Brea, Calif., USA). Insulin concentrations were determined by RIA using charcoal separation [14] and rat insulin standards (Lilly, Indianapolis, Ind., USA). The sensitivity of the assay was $30 \mathrm{pmol} / \mathrm{l}$.

Data presentation and statistical methods. All data are expressed as mean \pm SEM. Insulin output values in the tables are the mean insulin concentration of all samples collected during the designated perfusate condition. Dose-response curves for glucose-induced insulin secretion and glucose potentiation of arginine-induced insulin secretion were constructed by measuring insulin output at 5.5, 11.1, 16.7 , and $27.7 \mathrm{mmol} / \mathrm{l}$ glucose in separate groups of rats, then combining the results. Glucose concentration ( $x$ axis) was plotted against two types of $y$ axes, insulin output and percent maximal insulin output. Percent maximal output was calculated using the insulin concentration from the appropriate group perfused with $27.7 \mathrm{mmol} / 1$ glucose as $100 \%$. All groups had non-measurable insulin concentrations at the end of the 40 -min equilibration period at $0 \mathrm{mmol} / \mathrm{lglu}-$ cose so that a value of 0 was placed at $0 \mathrm{mmol} / \mathrm{l}$ glucose on all curves. Curves were fit to the data and half-maximal values calculated using a non-linear curve fit computer program (SigmaPlot; Jandel, San Rafael, Calif,, USA). Statistical significance was determined with the two-tailed unpaired Student's $t$-test (two groups) or one way analysis of variance (more than two groups).
A

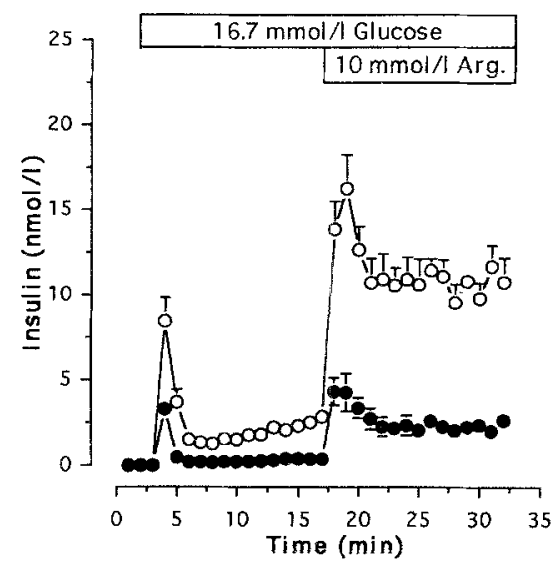

B

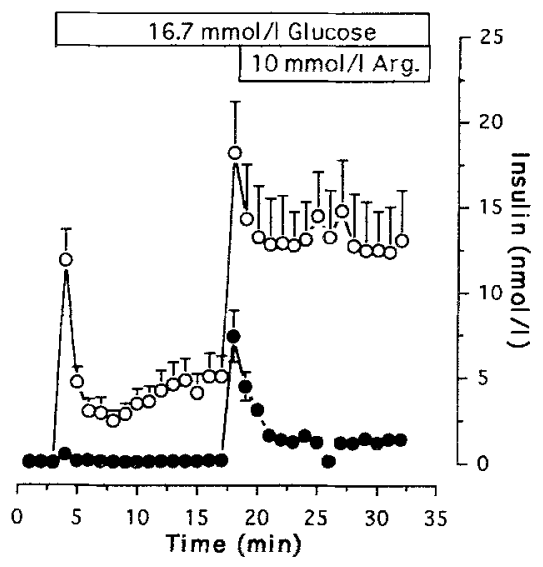

Fig.1 A, B. Insulin secretion 1 (A) and 2 (B) weeks after a $90 \%$ pancreatectomy $(-\bullet)$ or sham pancreatectomy $(0-0)$. Secretion was assessed in vitro with the perfused pancreas technique. Perfusion protocol: $5.5 \mathrm{mmol} / \mathrm{l}$ glucose followed by $15 \mathrm{~min}$ of $16.7 \mathrm{mmol} / \mathrm{l}$ glucose and $15 \mathrm{~min}$ of $16.7 \mathrm{mmol} / \mathrm{l}$ glucose $+10 \mathrm{mmol} / \mathrm{lar}-$ ginine. Groups consisted of 5 or 6 animals 
Table 2. Insulin secretion post $90 \%$ pancreatectomy

\begin{tabular}{|c|c|c|c|c|}
\hline \multirow[t]{2}{*}{ Week post-surgery } & \multirow[t]{2}{*}{ Animals $(n)$} & \multicolumn{2}{|c|}{ Insulin secretion $(\mathrm{pmol} / \mathrm{l})$} & \multirow{2}{*}{$\begin{array}{l}\text { Arginine/glucose } \\
\text { insulin response }\end{array}$} \\
\hline & & $16.7 \mathrm{mmol} / 1$ glucose & $\begin{array}{l}16.7 \mathrm{mmol} / 1 \text { glucose }+ \\
10 \mathrm{mmol} / \mathrm{l} \text { arginine }\end{array}$ & \\
\hline 1 week & $\begin{array}{l}\text { Sham (5) } \\
\operatorname{Px}(6)\end{array}$ & $\begin{array}{c}2480 \pm 132 \\
498 \pm 89 \\
(20 \pm 4 \%)\end{array}$ & $\begin{array}{r}11430 \pm 473 \\
2640 \pm 455 \\
(23 \pm 4 \%)\end{array}$ & $\begin{array}{l}4.7 \pm 0.3 \\
5.7 \pm 0.8\end{array}$ \\
\hline 2 weeks & $\begin{array}{l}\text { Sham (5) } \\
\operatorname{Px}(5)\end{array}$ & $\begin{array}{c}4510 \pm 984 \\
170 \pm 74 \\
(4 \pm 2 \%)\end{array}$ & $\begin{array}{c}13550 \pm 2600 \\
2120 \pm 457 \\
(16 \pm 3 \%)\end{array}$ & $\begin{array}{r}3.2 \pm 0.4 \\
16.6 \pm 4.2\end{array}$ \\
\hline
\end{tabular}

Values are expressed as mean \pm SEM. Insulin secretion results were obtained by in vitro pancreas perfusion using the protocol shown in Figure 1. Listed values are the mean insulin concentration of all sam- ples collected during the designated perfusate condition. The numbers in parentheses are the results from the $90 \%$ Px rats expressed as $\%$ of the result from the sham rats
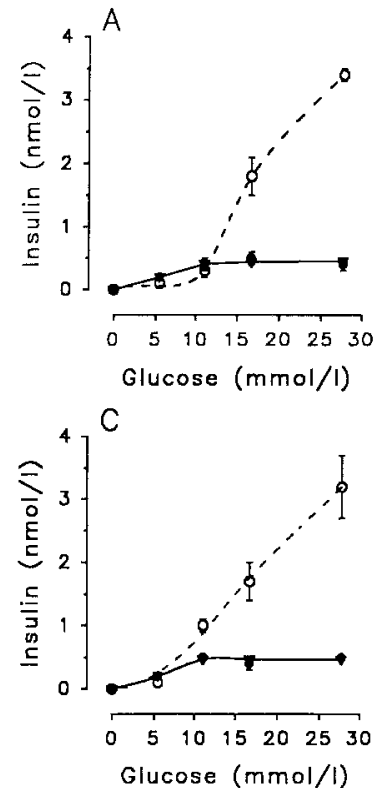

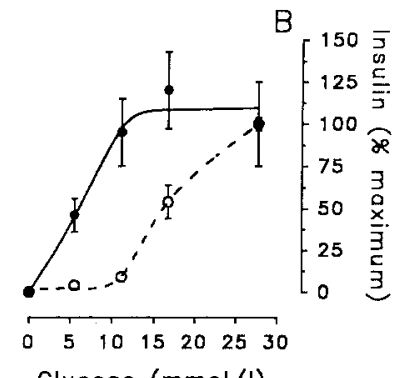

Glucose $(\mathrm{mmol} / \mathrm{I})$

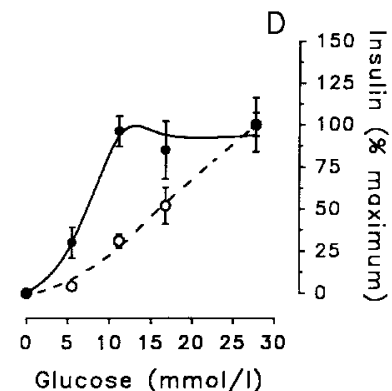

Fig. 2 A-D. Dose-response curves for glucose-induced insulin secretion 1 (upper panel) and 2 (lower panel) weeks after a $90 \%$ pancreatectomy $(-)$ ) or sham pancreatectomy $(0-0)$. Insulin secretion was assessed in vitro with the perfused pancreas technique. Perfusion protocol: $15 \mathrm{~min}$ of $5.5,11.1,16.7$, or $27.7 \mathrm{mmol} / \mathrm{l}$ glucose preceded by $40 \mathrm{~min}$ of $0 \mathrm{mmol} / \mathrm{lglucose}$. Each point represents the mean effluent insulin concentration from a separate group of rats (34 perfusions). A insulin output 1 week post-surgery. B \% maximal insulin output 1 week post-surgery. C insulin output 2 weeks postsurgery. D \% maximal insulin output 2 weeks post-surgery

\section{Results}

General characteristics of the animal groups (Table 1). Rats 1 week post $90 \%$ Px weighed slightly less than sham rats. By 2 weeks, the body weight was back to normal. Non-fasting plasma glucose values peaked 1 week after a $90 \% \mathrm{Px}$ at $2-3 \mathrm{mmol} / \mathrm{l}$ above normal.

Protocol 1. Glucose and arginine-induced insulin secretion were assessed 1 and 2 weeks post $90 \%$ Px. The perfusion protocol was $5.5 \mathrm{mmol} / \mathrm{l}$ glucose during the equilibration period followed by $15 \mathrm{~min} 16.7 \mathrm{mmol} / \mathrm{lglucose}$ and $15 \mathrm{~min} 16.7 \mathrm{mmol} / \mathrm{l}$ glucose $+10 \mathrm{mmol} / \mathrm{l}$ arginine (Fig. 1 ). One week post-surgery, sham rats had the expected biphasic rise in insulin release to $16.7 \mathrm{mmol} / \mathrm{l}$ glucose and a

further $4.7 \pm 0.3$ fold rise when arginine was added. The results at 2 weeks were similar except for a larger insulin response to $16.7 \mathrm{mmol} / \mathrm{l}$ glucose. One week post $90 \% \mathrm{Px}$, insulin secretion was similar to that of the sham rats when the reduced beta-cell mass was taken into account; the glucose response was $20 \pm 4 \%$ of the shams, the arginine response was $23 \pm 4 \%$, and the fold rise to arginine was like that of the sham rats (Table 2). The only abnormality was a shift in the pattern of insulin release towards an exaggerated first phase response to $16.7 \mathrm{mmol} / \mathrm{l}$ glucose (first phase $26 \pm 4 \%$ of shams vs second phase $15 \pm 4 \%$ of shams, $p<0.005$ by paired $t$-test). Two weeks post $90 \%$ $\mathrm{Px}$, the insulin response to $16.7 \mathrm{mmol} / \mathrm{l}$ glucose had fallen to $4 \pm 2 \%$ of the sham rats while that to arginine $(16 \pm 3 \%)$ was still in line with the expected fractional beta-cell mass of the pancreatic remnant.

Protocol 2. Dose-response curves for glucose-induced insulin secretion and glucose potentiation of arginine-induced insulin secretion were constructed 1 and 2 weeks post $90 \%$ Px by perfusing rats with $5.5,11.1,16.7$, or $27.7 \mathrm{mmol} / \mathrm{l}$ glucose followed by the addition of $10 \mathrm{mmol} / \mathrm{l}$ arginine. It has previously been established that perfusing the pancreas of diabetic rats for 40 min with buffer containing no glucose causes re-emergence of glucose-induced insulin secretion [7]. Protocol 1 showed virtual absence of glucose-induced insulin secretion in $90 \%$ Px rats 2 weeks after the surgery. In order to allow study of the beta-cell sensitivity for glucose 1 and 2 weeks postsurgery, the protocol began with $40 \mathrm{~min} 0 \mathrm{mmol} / \mathrm{l}$ glucose.

In sham rats, the curves for glucose-induced insulin secretion at 1 and 2 weeks were superimposable (Fig. 2); both showed the typical $\mathrm{S}$ shape with output rising through $27.7 \mathrm{mmol} / 1$ glucose. The glucose values for halfmaximal insulin output were $16.5 \mathrm{mmol} / \mathrm{l}$ at 1 week and $16.5 \mathrm{mmol} / \mathrm{l}$ at 2 weeks. The curves in the $90 \%$ Px rats were very different, rising steeply to a maximum response at $11.1 \mathrm{mmol} / 1$ glucose. The half-maximal insulin output values were $5.7 \mathrm{mmol} / \mathrm{l}$ glucose at 1 week and $5.6 \mathrm{mmol} / \mathrm{l}$ glucose at 2 weeks. Glucose potentiation of arginine-induced insulin output was also shifted to the left in the $90 \%$ Px rats. The curves in the shams were sigmoidal with halfmaximal values at 1 and 2 weeks of 14.8 and $15.8 \mathrm{mmol} / 1$ glucose (Fig. 3). The 90\% Px rats had hyperbolic curves with half-maximal values at 1 and 2 weeks of $3.5 \mathrm{mmol} / 1$ and $6.6 \mathrm{mmol} / \mathrm{l}$ glucose. 

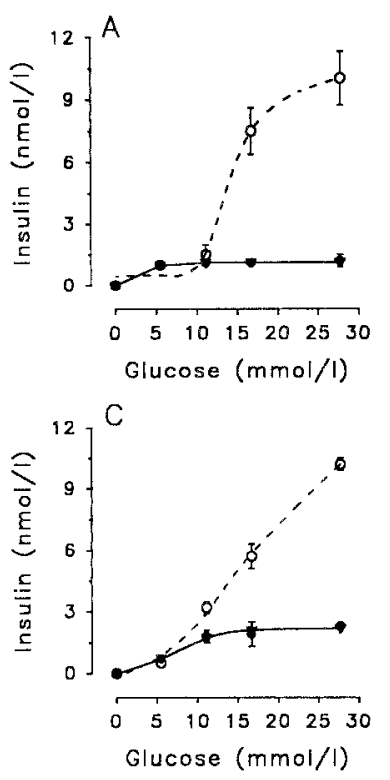

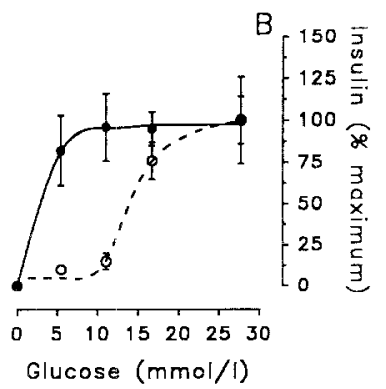

Glucose $(\mathrm{mmol} / \mathrm{i})$

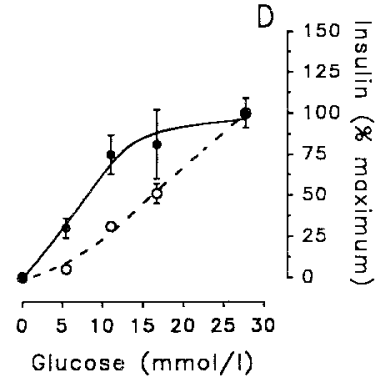

Fig.3A-D. Dose-response curves for glucose potentiation of arginine-induced insulin secretion 1 (upper panel) and 2 (lower panel) weeks after a $90 \%$ pancreatectomy (-) or sham pancreatectomy $(\mathrm{O}-\mathrm{O})$. Insulin secretion was assessed in vitro with the perfused pancreas technique. Perfusion protocol: $15 \mathrm{~min}$ of $10 \mathrm{mmol} / \mathrm{l}$ arginine $+5.5,11.1,16.7$, or $27.7 \mathrm{mmol} / 1$ glucose preceded by $40 \mathrm{~min}$ of $0 \mathrm{mmol} / \mathrm{l}$ glucose and $15 \mathrm{~min}$ of the same glucose concentration. Each point represents the mean effluent insulin concentration from a separate group of rats (3-4 perfusions). A insulin output 1 week post-surgery. B $\%$ maximal insulin output 1 week post-surgery. C insulin output 2 weeks post-surgery. D \% maximal insulin output 2 weeks post-surgery

To determine which phases of glucose-induced insulin secretion were shifted to the left in $90 \%$ Px rats, separate dose-response curves for the first and second phases were constructed in 1 week post-surgery rats using the data from Figure $2 \mathrm{~A}$. The curves for first and second phase release were both left-shifted in the $90 \%$ Px rats (Fig. 4); half-maximal values were $5.3 \mathrm{mmol} / 1$ glucose in $90 \% \mathrm{Px}$ rats for the first phase vs $13.4 \mathrm{mmol} / \mathrm{lglucose}$ in shams, and $6.9 \mathrm{mmol} / \mathrm{lglucose}$ in $90 \% \mathrm{Px}$ rats for the second phase vs $17.1 \mathrm{mmol} / \mathrm{l}$ glucose in shams. In addition, close examination of these data provided additional support for the observation from protocol 1 of an abnormal pattern of glucose-induced insulin secretion in $90 \%$ Px rats which is characterized by an exaggerated first phase. As shown in Table 3, the mean insulin levels attained during $27.7 \mathrm{mmol} / \mathrm{lglucose}$ in the sham rats were similar for the first and second phases $(2773 \pm 459 \mathrm{pmol} / 1$ first phase vs $3600 \pm 227 \mathrm{pmol} / 1$ second phase, $p=\mathrm{NS}$ ). In contrast, in $90 \%$ Px rats, the mean first phase level was 4 times higher than the second phase $(919 \pm 209 \mathrm{pmol} / 1$ first phase vs $211 \pm 31 \mathrm{pmol} / \mathrm{l}$ second phase, $p<0.03$ ). The same pattern was observed in the $90 \%$ Px rats 2 weeks post-surgery (Table 3).

Protocol 3. To determine if hyperglycaemia caused the heightened beta-cell sensitivity for glucose in $90 \%$ Px rats, dose-response curves for glucose-induced insulin secretion and glucose potentiation of arginine-induced insulin secretion were constructed 2 weeks after a $60 \%$ Px using the
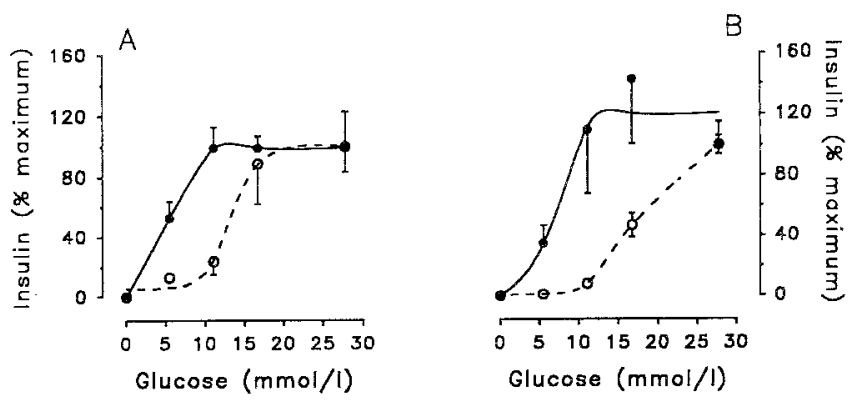

Fig. 4A, B. Dose-response curves for first and second phases of glucose-induced insulin secretion 1 week after a $90 \%$ pancreatectomy $(-)$ or sham pancreatectomy $(\mathrm{O}-0)$. Insulin secretion was assessed in vitro with the perfused pancreas technique. Perfusion protocol: $15 \mathrm{~min}$ of $5.5,11.1,16.7$, or $27.7 \mathrm{mmol} / 1$ glucose preceded by $40 \mathrm{~min}$ of $0 \mathrm{mmol} / 1$ glucose. First phase release was calculated as the mean insulin concentration of the samples obtained during min $2-5$. Second phase release was calculated as the mean insulin concentration of the samples obtained during min 6-15. Each point represents a separate group of rats ( $3-4$ perfusions). A \% maximal first phase insulin release. $\mathbf{B} \%$ maximal second phase insulin release
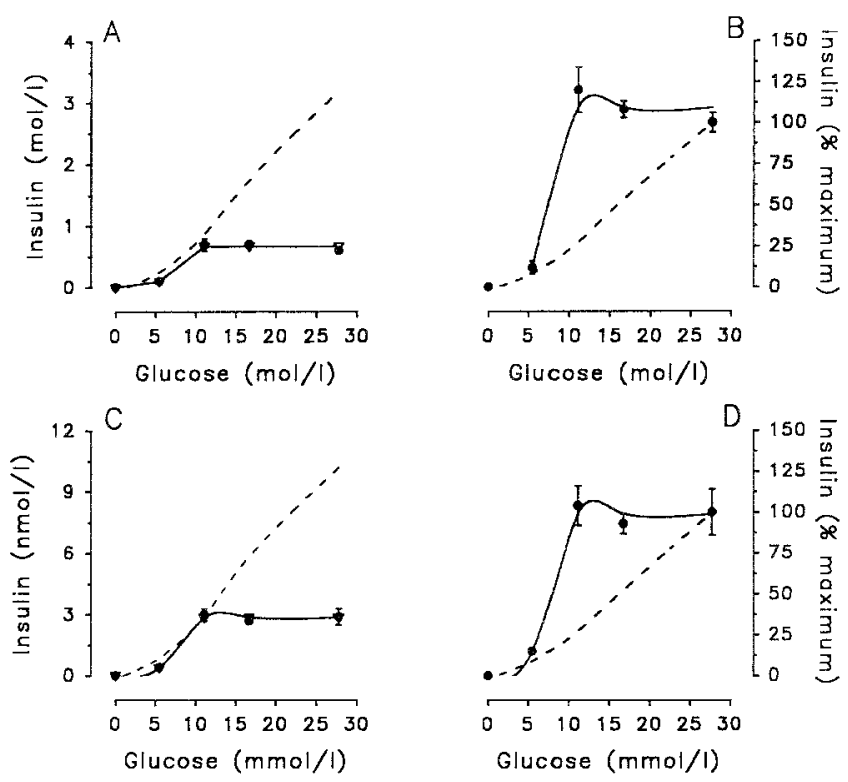

Fig.5A-D. Dose-response curves for glucose-induced insulin secretion (upper panel) and glucose potentiation of arginine-induced insulin secretion (lower panel) 2 weeks after a $60 \%$ pancreatectomy $(-)$. The dashed line repeats the 2 -week results of the sham rats from Figures 2 and 3. Insulin secretion was assessed in vitro with the perfused pancreas technique. Perfusion protocol: 40 min equilibration at $0 \mathrm{mmol} / \mathrm{l}$ glucose followed by $15 \mathrm{~min}$ of $5.5,11.1,16.7$, or $27.7 \mathrm{mmol} / 1$ glucose and $15 \mathrm{~min}$ of $10 \mathrm{mmol} / 1$ arginine + the same glucose concentration. Each point represents the mean effluent insulin concentration from a separate group of rats (3-5 perfusions). A insulin output to glucose. B \% maximal insulin output to glucose. $\mathbf{C}$ insulin output to arginine + glucose. $\mathbf{D} \%$ maximal insulin output to arginine + glucose

method described above, $40 \mathrm{~min}$ of $0 \mathrm{mmol} / \mathrm{l}$ glucose followed by $5.5,11.1,16.7$, or $27.7 \mathrm{mmol} / 1$ glucose, then $10 \mathrm{mmol} / \mathrm{l}$ arginine + the same glucose concentration. Non-fasting plasma glucose values were normal 2 weeks after a $60 \% \mathrm{Px}$ (Table 1). Despite having removed $60 \%$ of the pancreas, insulin output to glucose and to arginine per- 
Table 3. First and second phases of insulin secretion post $60 \%$ and $90 \%$ pancreatectomy

\begin{tabular}{|c|c|c|c|c|c|c|}
\hline \multirow{3}{*}{$\begin{array}{l}\text { Perfusate glucose } \\
(\mathrm{mmol} / \mathrm{l})\end{array}$} & & \multicolumn{5}{|c|}{ Insulin secretion $(\mathrm{pmol} / \mathrm{l})$} \\
\hline & & \multicolumn{2}{|c|}{ Sham rats 1 week post-surgery } & \multicolumn{3}{|c|}{$90 \%$ Px 1 week post-surgery } \\
\hline & & First phase & Second phase & \multicolumn{2}{|l|}{ First phase } & Second phase \\
\hline 11.1 & & $656 \pm 254$ & $275 \pm 97$ & \multicolumn{2}{|l|}{$908 \pm 124$} & $231 \pm 88$ \\
\hline 16.7 & & $2472 \pm 750$ & $1722 \pm 294$ & $905 \pm 73$ & \multicolumn{2}{|c|}{$301 \pm 87$} \\
\hline \multirow[t]{3}{*}{27.7} & & $2773 \pm 459$ & $3600 \pm 227$ & $919 \pm 209$ & \multicolumn{2}{|c|}{$211 \pm 31$} \\
\hline & \multicolumn{2}{|c|}{ Sham rats 2 weeks post-surgery } & \multicolumn{2}{|c|}{$60 \%$ Px rats 2 weeks post-surgery } & \multicolumn{2}{|c|}{$90 \%$ Px rats 2 weeks post-surgery } \\
\hline & First phase & Second phase & First phase & Second phase & First phase & Second phase \\
\hline 5.5 & $457 \pm 20$ & $24 \pm 6$ & $279 \pm 101$ & $26 \pm 7$ & $362 \pm 46$ & $81 \pm 41$ \\
\hline 11.1 & $2082 \pm 262$ & $743 \pm 116$ & $1268 \pm 144$ & $613 \pm 84$ & $1192 \pm 210$ & $249 \pm 24$ \\
\hline 16.7 & $2384 \pm 417$ & $1769 \pm 408$ & $1151 \pm 90$ & $499 \pm 73$ & $1290 \pm 61$ & $196 \pm 33$ \\
\hline 27.7 & $3956 \pm 497$ & $3241 \pm 565$ & $1063 \pm 79$ & $576 \pm 75$ & $1418 \pm 173$ & $300 \pm 57$ \\
\hline
\end{tabular}

Values are expressed as mean \pm SEM. Insulin secretion results were obtained by in vitro pancreas perfusion using a protocol of $40 \mathrm{~min}$ $0 \mathrm{mmol} / \mathrm{l}$ glucose followed by $15 \mathrm{~min}$ of one of the glucose concentra- tions shown. First phase release: mean insulin concentration of the samples obtained during min 2-5. Second phase release: mean insulin concentration of the samples obtained during min $6-15$ fectly matched that of sham rats up to $11.1 \mathrm{mmol} / \mathrm{l}$ glucose (Fig. 5), thereafter, output rose no further. The half-maxi$\mathrm{mal}$ insulin output values were $6.2 \mathrm{mmol} / \mathrm{l}$ glucose for glucose-induced insulin secretion $-6.0 \mathrm{mmol} / \mathrm{l}$ glucose first phase and $6.6 \mathrm{mmol} / \mathrm{l}$ glucose second phase - and $6.1 \mathrm{mmol} / \mathrm{l}$ glucose for the arginine response. Like the $90 \%$ Px rats, the pattern of glucose-induced insulin secretion in the $60 \%$ Px rats was altered towards an exaggerated first phase response. As seen previously at 1 -week post-surgery, sham rats 2 weeks post-surgery had mean first and second phase insulin concentrations at $27.7 \mathrm{mmol} / 1$ glucose that were similar $(3956 \pm 497 \mathrm{pmol} / 1$ first phase vs $3241 \pm 565 \mathrm{pmol} / \mathrm{l}$ second phase, $p=\mathrm{NS}$ ). In contrast, the mean insulin level for the first phase in the $60 \% \mathrm{Px}$ rats was double the second phase $(1063 \pm 79 \mathrm{pmol} / 1$ first phase vs $576 \pm 75 \mathrm{pmol} / \mathrm{l}$ second phase, $p<0.011)$.

\section{Discussion}

Normally, the plasma glucose concentration controls insulin secretion through its actions to stimulate insulin release and to modulate insulin output from other secretagogues. Chronic hyperglycaemia disrupts this relationship such that glucose control over insulin release is impaired [3]. The present paper has studied insulin secretion in a diabetic rat model prior to the time that the beta cells became unresponsive to glucose. For the first time, an intermediate stage in beta-cell function has been identified which is characterized by a raised sensitivity for glucose as defined by left-shifted curves for glucose-induced insulin secretion and glucose potentiation of arginine-induced insulin secretion. These results delineate the sequence of changes in beta-cell function which accompany chronic hyperglycaemia. First, glucose sensitivity increases. The result is that normal to near-normal levels of plasma glucose cause substantially more insulin output than expected. Sometime later, glucose-induced insulin secretion disappears.

Why did the beta-cell sensitivity for glucose increase? We previously reported a left-shifted dose-response curve for glucose-induced insulin secretion in another diabetic rat model, rats given streptozotocin as neonates [8]. In the current study, the left-shifts were identified 1 -week post $90 \%$ Px when the rats were hyperglycaemic. It is tempting to speculate that the hyperglycaemia caused the increased sensitivity for glucose. Additional experimental data which could be interpreted to support such an idea are that isolated islets from rats made hyperglycaemic with glucose infusions $[15,16]$ and normal islets cultured at a high glucose concentration [17] both have left-shifted curves for glucose-induced insulin secretion. However, $60 \%$ Px rats showed similar reductions in half-maximal insulin responses to glucose as the $90 \% \mathrm{Px}$ rats despite their normoglycaemia. Ward et al. $[2,18]$ reported a left-shift in glucose potentiation of arginine-induced insulin secretion in normoglycaemic dogs 4 weeks after a two-thirds pancreatectomy. Also, glucose-induced insulin secretion is left-shifted in obese normoglycaemic rats $[19,20]$ and in normoglycaemic pregnant rats [21]. Therefore, hyperglycaemia does not appear to be a factor in the raised betacell sensitivity for glucose. Instead, these situations all have a raised demand for insulin output because of reductions in beta-cell mass, insulin resistance, and/or hyperglycaemia. Our working model is that the supersensitivity for glucose represents an adaptive response of beta cells to an increased work load. With that idea in mind, the results in the $60 \%$ Px rats provided a striking demonstration of just how successful the beta-cell adaption was; despite there being $60 \%$ fewer beta cells, insulin output to glucose and to arginine perfectly matched that of the sham rats over the physiologic range of glucose concentrations. Whether human beta cells adapt in quite the same fashion remains unknown, since normal half-maximal responses for glucose-induced insulin secretion have been reported following a partial pancreatectomy [22] and with experimental insulin resistance [23].

A key question from these results is whether the betacell supersensitivity for glucose in the $90 \%$ Px rats plays any role in the later disappearance of glucose-induced insulin secretion. Such a model could entail chronic stimulation of beta cells leading to depletion or alteration of key 
substrates, cofactors, or regulatory enzymes. Extrapolating our data to the in vivo situation, at their usual levels of glycaemia, the beta cells of sham rats $(8.1 \mathrm{mmol} / \mathrm{l}$ of glucose) secreted at $8 \%$ of their secretory capacity while the Px rats $(10.6 \mathrm{mmol} / \mathrm{l}$ glucose $)$ were at more than $90 \%$ of capacity. Finding the left-shifted curves in the euglycaemic $60 \%$ Px rats, a model known to maintain normal beta cell responsiveness to glucose [5], does not exclude this possibility since hyperglycaemia would have an additive effect to further stimulate insulin output. It may be that both factors must be present to reach a level of function which is not sustainable. The approach taken to test the role that overwork plays in the beta-cell glucose unresponsiveness from chronic hyperglycaemia has been to investigate the effects of diazoxide, an inhibitor of insulin secretion which acts to tonically open ATP-sensitive $\mathrm{K}^{+}$ channels, thereby preventing beta-cell depolarization [9, 24]. The published data are contradictory in that diazoxide has been reported to prevent the loss of glucose-induced insulin secretion in rats made hyperglycaemic by glucose infusions [9]. In contrast, diazoxide failed to cause recovery of glucose-induced insulin secretion in a rat model with pre-existing glucose unresponsiveness when studied under basal conditions, but did increase the insulin response to glucose when the rats were made more hyperglycaemic with glucose infusions [25]. Preliminary experiments from our laboratory have found marked increases in insulin responses using diazoxide treatment in $90 \%$ Px rats [26].

In summary, this paper has mapped out the temporal profile of changes in beta-cell function that follow a $90 \%$ pancreatectomy in rats. The same sequence is thought to occur with chronic hyperglycaemia regardless of cause. The first change is an increase in glucose sensitivity as defined by reductions in the thresholds for glucose-induced insulin secretion and glucose potentiation of arginine-induced insulin secretion. The shift to a supersensitive beta cell occurred within 1 week of the surgery, at a time when the rats were hyperglycaemic. However, hyperglycaemia played little to no role in the heightened . glucose sensitivity. Instead, the rise in glucose sensitivity represented an adaptive response of beta cells to the increased demand for insulin output. By 2 weeks after the surgery, a second beta-cell defect appeared, a near-total inhibition of glucose-induced insulin secretion. Hyperglycaemia has been postulated to be necessary for this defect to occur [3]. The hypersensitivity to glucose is still present, but it is hidden by the impairment in glucose-induced insulin secretion. This fact becomes evident when the dose-response curves at 1 and 2 weeks are compared; experimentally reversing the block in glucose-induced insulin secretion with $40 \mathrm{~min}$ of $0 \mathrm{mmol} / \mathrm{l}$ glucose resulted in curves at the two time points which were essentially identical. These results clearly indicate that the hypersensitivity to glucose and the impairment in glucose-induced insulin secretion are separate and distinct defects.

Acknowledgements. This work was supported by National Institutes of Health grant DK-36836. Dr. Chen is supported by a postdoctoral fellowship from the Juvenile Diabetes Foundation.

\section{References}

1. Leahy JL (1990) Natural history of $\beta$-cell dysfunction in NIDDM. Diabetes Care 13: 992-1010

2. Porte D Jr. (1991) $\beta$-cells in type II diabetes mellitus. Diabetes 40: $166-180$

3. Leahy JL, Bonner-Weir S, Weir GC (1992) Beta-cell dysfunction induced by chronic hyperglycemia: current ideas on the mechanism of the impaired glucose-induced insulin secretion. Diabetes Care 15: $442-455$

4. Trent DF, Fletcher DJ, May JM, Bonner-Weir S, Weir GC (1984) Abnormal islet and adipocyte function in young $B$-cell deficient rats with near-normoglycemia. Diabetes 33: 170-175

5. Leahy JL, Bonner-Weir S, Weir GC (1988) Minimal chronic hyperglycemia is a critical determinant of impaired insulin secretion after an incomplete pancreatectomy. J Clin Invest 81: 14071414

6. Leahy JL, Copper HE, Weir GC (1987) Impaired insulin secretion associated with near normoglycemia: study in normal rats with 96-h in vivo glucose infusions. Diabetes 36: 459-464

7. Grill V, Westberg M, Östenson C-G (1987) B-cell insensitivity in a rat model of non-insulin-dependent diabetes: evidence for a rapidly reversible effect of previous hyperglycemia. J Clin Invest 80: 664-669

8. Chen C, Thorens B, Bonner-Weir S, Weir GC, Leahy JL (1992) Recovery of glucose-induced insulin secretion in a rat model of NIDDM is not accompanied by return of the B-cell GLUT2 glucose transporter. Diabetes 41: 1320-1327

9. Sako Y, Grill VE (1990) Coupling of B-cell desensitization by hyperglycemia to excessive stimulation and circulating insulin in glucose-infused rats. Diabetes 39: 1580-1583

10. Bonner-Weir S, Trent DF, Weir GC (1983) Partial pancreatectomy in the rat and subsequent defect in glucose-induced insulin release. J Clin Invest 71: 1544-1553

11. Leahy JL, Bonner-Weir S, Weir GC (1984) Abnormal glucose regulation of insulin secretion in models of reduced B-cell mass. Diabetes 33: 667-673

12. Jansson L, Sandler S (1989) Pancreatic and islet blood flow in the regenerating pancreas after partial pancreatectomy in adult rats. Surgery 106: 861-866

13. Weir GC, Knowlton SD, Martin DB (1974) Glucagon secretion from the perfused rat pancreas: studies with glucose and catecholamines. J Clin Invest 54: 1403-1412

14. Albano JDM, Ekins RP, Maritz G, Turner RC (1972) A sensitive, precise radioimmunoassay of serum insulin relying on charcoal separation of bound and free hormone moieties. Acta Endocrinol 70: 487-509

15. Timmers KI, Powell AM, Voyles NR et al. (1990) Multiple alterations in insulin responses to glucose in islets from 48 -h glucoseinfused nondiabetic rats. Diabetes 39: 1436-1444

16. Marynissen G, Leclercq-Meyer V, Sener A, Malaisse WJ (1990) Perturbation of pancreatic islet function in glucose-infused rats. Metabolism 39: 87-95

17. Purrello F, Vetri M, Gatta C, Gullo D, Vigneri R (1989) Effects of high glucose on insulin secretion by isolated rat islets and purified $\beta$-cells and possible role of glycosylation. Diabetes 38: 14171422

18. Ward WK, Wallum BJ, Beard JC, Taborsky GJ Jr, Porte D Jr (1988) Reduction of glycemic potentiation: sensitive indicator of $\beta$-cell loss in partially pancreatectomized dogs. Diabetes 37 : $723-$ 729

19. Curry DL, Stern JS (1985) Dynamics of insulin hypersecretion by obese Zucker rats. Metabolism 34: 791-796

20. Timmers KI, Voyles NR, Recant L (1993) Genetically obese rats with (SHR/N-cp) and without diabetes (LA/N-cp) share abnormal islet responses to glucose. Metabolism 41:1125-1133

21. Parsons JA, Brelje TC, Sorenson RL (1992) Adaption of islets of Langerhans to pregnancy: increased islet cell proliferation and insulin secretion correlates with the onset of placental lactogen secretion. Endocrinology 130: 1459-1466 
22. Seaquist ER, Robertson RP (1992) Effects of hemipancreatectomy on pancreatic alpha and beta cell function in healthy human donors. J Clin Invest 89: 1761-1766

23. Kahn SE, Beard JC, Schwartz MW et al. (1989) Increased $\beta$-cell secretory capacity as mechanism for islet adaption to nicotinic acid-induced insulin resistance. Diabetes 38: 562-568

24. Trube G, Rorsman P, Shosaku O (1986) Opposite effects of tolbutamide and diazoxide on the ATP dependent $\mathrm{K}^{+}$channel in mouse pancreatic B-cells. Pfluegers Arch Eur J Physiol 407:493499

25. Sako Y, Grill VE (1992) Diazoxide infusion at excess but not at basal hyperglycemia enhances $\beta$-cell sensitivity to glucose in vitro in neonatally streptozotocin-diabetic rats. Metabolism 41: $738-743$
26. Leahy JL (1993) $\beta$-cell hypersensitivity to glucose is one cause of lost glucose-induced insulin secretion in diabetic rats. Diabetes 42 [Suppl 1]: 69 A (Abstract)

Received: 19 April 1993

and in revised form: 29 June 1993

Dr. J. L. Leahy

New England Medical Center \# 268

750 Washington Street

Boston, MA 02111

USA 